\title{
Similar Aggressiveness of Phenotypically and Genotypically Distinct Isolates of Sclerotinia sclerotiorum
}

M. S. Lehner, Programa de Pós-graduação em Genética e Melhoramento, Universidade Federal de Viçosa, 36570-000 Viçosa, MG, Brasil; R. C. Lima and J. E. S. Carneiro, Departamento de Fitotecnia, Universidade Federal de Viçosa, 36570-000 Viçosa, MG, Brasil; T. J. Paula Júnior and R. F. Vieira, Empresa de Pesquisa Agropecuária de Minas Gerais (EPAMIG), 36570-000 Viçosa, MG, Brasil; and E. S. G. Mizubuti, Departamento de Fitopatologia, Universidade Federal de Viçosa, 36570-000 Viçosa, MG, Brasil

\begin{abstract}
Lehner, M. S., Lima, R. C., Carneiro, J. E. S., Paula Júnior, T. J., Vieira, R. F., and Mizubuti, E. S. G. 2016. Similar aggressiveness of phenotypically and genotypically distinct isolates of Sclerotinia sclerotiorum. Plant Dis. 100:360-366.

Understanding how Sclerotinia sclerotiorum aggressiveness varies among isolates may be useful for breeding programs aimed at developing common bean cultivars resistant to white mold. The aggressiveness of 20 S. sclerotiorum isolates collected in common bean fields from four Brazilian states was tested against two common bean genotypes (Pérola and A195) using two inoculation methods. The isolates were characterized using 10 microsatellite (SSR) loci, mycelial compatibility groups

(MCGs), partial sequences of the oxaloacetate acetylhydrolase (OAH) gene, and morphological traits. Twenty SSR and seven OAH haplotypes, 10 MCGs, and high variability in colony morphology were found. One isolate was more aggressive when inoculated on plants of the genotype A195, but all other isolates had similar aggressiveness. Aggressiveness was not related with MCGs, SSR, OAH haplotypes, mycelial pigmentation, growth rate, or sclerotia production.
\end{abstract}

Sclerotinia sclerotiorum (Lib.) de Bary is a necrotrophic fungus with a broad host range that causes white mold on common bean (Phaseolus vulgaris L.) (Boland and Hall 1994). This fungus is widespread, and severe white mold epidemics are frequently observed in the common bean producing areas in Brazil. White mold management depends almost exclusively on fungicide applications at the flowering stage (Vieira et al. 2010). However, there is increasing interest in alternative strategies, especially genetic resistance, to control white mold, given that the use of resistant common bean cultivars is a promising option (Schwartz and Singh 2013).

The current breeding strategy for minimizing damage caused by white mold on common bean is based on the combination of physiological and avoidance resistance. Physiological resistance is conferred by plant defense mechanisms and avoidance by plant architecture-related traits (Miklas et al. 2013). Under field conditions, both types of resistance contribute to white mold control, whereas in the greenhouse or laboratory, only physiological resistance can be identified (Vuong et al. 2004).

Finding new sources of resistance to white mold requires reliable disease evaluation techniques and proper understanding of pathogenic variability of $S$. sclerotiorum (Kull et al. 2003). Thus, common bean germplasm should be screened against appropriate $S$. sclerotiorum isolates, preferably genetically distinct and collected in regions where cultivars will be released (Schwartz and Singh 2013). The inoculation method can also influence the response of common bean genotypes to white mold (Kull et al. 2003). Two tests are often used to assess physiological resistance to white mold in common bean: inoculation of detached leaflets (Steadman et al. 1997) and the straw test (Petzoldt and Dickson 1996). Detached leaflets is a repeatable method that allows many common bean genotypes to be tested rapidly (Kull et al. 2003). In the straw test, the fungus is inoculated on

\section{Corresponding author: Eduardo S. G. Mizubuti, E-mail: mizubuti@ufv.br}

* The $e$-Xtra logo stands for "electronic extra" and indicates that one supplementary table and one supplementary figure are included in the online edition.

Accepted for publication 18 June 2015.

http://dx.doi.org/10.1094/PDIS-04-15-0400-RE

(C) 2016 The American Phytopathological Society the stem of plants and the severity assessed using a 1 to 9 scale or by measuring the lesion length. Currently, the straw test is the most widely used method for detection of physiological resistance to white mold (Schwartz and Singh 2013).

In Brazil, assays aimed at screening for resistance to white mold have been carried out using the straw test method (Carneiro et al. 2010; Carvalho et al. 2013). Usually, pathogen variation has not been considered in these studies, because little is known about the variability of S. sclerotiorum aggressiveness in the common bean-producing areas. Recently, studies were conducted to assess the genetic variability of S. sclerotiorum isolates from common bean fields in Brazil (Lehner et al. 2014, 2015). Using microsatellite markers and mycelial compatibility groups (MCGs), low genetic variability was found (Lehner et al. 2015), although there is high variability in morphological traits, such as mycelial pigmentation, growth rate, and sclerotia production (Lehner et al. 2014). Nonetheless, variation in aggressiveness was not assessed in these studies.

Variation in aggressiveness is often assessed by measuring variables associated with the disease signs and symptoms. Studies designed to address aggressiveness of $S$. sclerotiorum have been done with the most economically important hosts of the pathogen: soybean (Kull et al. 2004), potato (Atallah et al. 2004), canola (Attanayake et al. 2013; Sexton and Howlett 2004), sunflower (Ekins et al. 2007; Irani et al. 2011), and common bean (Otto-Hanson et al. 2011; Pascual et al. 2010). In one study with common bean, Otto-Hanson et al. (2011) tested 156 isolates, 138 from the United States and 18 from France. In another paper, four isolates from Spain were assessed for differences in aggressiveness (Pascual et al. 2010). No studies were conducted to evaluate variation in aggressiveness among isolates of S. sclerotiorum from common bean fields in Brazil, one of the largest world producers of this legume. In addition, few studies have addressed the relationship between aggressiveness and molecular or morphological markers.

The purpose of this study was to compare the aggressiveness of S. sclerotiorum isolates collected from distinct common bean fields in Brazil and to determine the relationship between aggressiveness and genetic variability of the isolates.

\section{Materials and Methods}

Fungal isolates and DNA extraction. Sclerotia of S. sclerotiorum were collected from plants with symptoms of white mold in 20 common bean fields between 2010 and 2012. The fields were located in 
four states, which together account for about $50 \%$ of the bean production in Brazil (IBGE 2015). Sclerotia were collected in the municipalities of Oratórios, Canaã, Viçosa, Porto Firme, Paracatu (2 fields), and Unaí (3 fields), in Minas Gerais state; Itaí, Capão Bonito (2 fields), and Itararé, in São Paulo state; Santa Maria do Jetibá (2 fields) and Domingos Martins, in Espírito Santo state; and Mauá da Serra, Corbélia, Reserva do Iguaçu, and Três Barras, in Paraná state. To ensure genetic uniformity, only hyphal-tip or monoascosporic isolates were used in the tests (Table 1). To obtain hyphal-tip isolates, one sclerotium from each sampled field was arbitrarily chosen, disinfested using standard procedures (Lehner et al. 2015), transferred to petri dishes ( $90 \mathrm{~mm}$ diameter) containing PDA medium, and incubated at $23^{\circ} \mathrm{C}$ for 6 days for mycelium growth. The tip of an individualized hypha was cut with a scalpel and transferred to freshly prepared PDA dishes, which were maintained at $23^{\circ} \mathrm{C}$ in the dark for 10 to 15 days. To obtain monoascosporic isolates, the sclerotium was buried at a depth of $5 \mathrm{~mm}$ in autoclaved sand and incubated at $18^{\circ} \mathrm{C} / 12 \mathrm{~h}$ photoperiod for production of apothecia. Tap water was sprayed every day on the sand to keep the high humidity needed for carpogenic germination. One mature apothecium of each sclerotium was collected and inverted over a petri dish containing $2 \%$ water agar (Atallah et al. 2004). One ascospore of each sclerotium was arbitrary selected using a stereomicroscope and transferred to PDA using an insulin needle. Sclerotia produced by colonies of the hyphal tip or single ascospore isolates were dried and stored at $4{ }^{\circ} \mathrm{C}$.

All isolates were confirmed to be $S$. sclerotiorum as previously described (Lehner et al. 2015) using the specific primer pair SSasprF/SSasprR (Abd-Elmagid et al. 2013). To extract DNA, isolates were grown in liquid medium ( $10 \mathrm{~g}$ sucrose, $2 \mathrm{~g}$ l-asparagin,

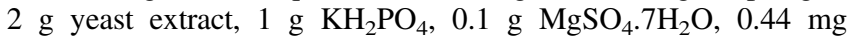
$\mathrm{ZnSO}_{4} \cdot 7 \mathrm{H}_{2} \mathrm{O}, 0.48 \mathrm{mg} \mathrm{FeCl} 3 \cdot 6 \mathrm{H}_{2} \mathrm{O}$, and $\left.0.36 \mathrm{mg} \mathrm{MnCl}_{2} \cdot \mathrm{H}_{2} \mathrm{O}\right)$ in Erlenmeyer flasks at $23^{\circ} \mathrm{C}$ for 7 days. The mycelium was washed with distilled water, transferred to filter paper to dry, and macerated in a mortar with liquid nitrogen. DNA was extracted using the Wizard Genomic DNA Purification Kit (Promega, Madison, WI) following the manufacturer's instructions. DNA integrity was analyzed in agarose gel electrophoresis, and its concentration was measured in a spectrophotometer (Nanodrop 2000, Thermo Scientific, Wilmington, DE).

Mycelial compatibility group. Mycelial compatibility was evaluated according to Schafer and Kohn (2006). The S. sclerotiorum isolates were paired in petri dishes $(60 \times 15 \mathrm{~mm})$ containing PDA amended with $75 \mu 1 /$ liter of McCormick's red food coloring. Disks ( $5 \mathrm{~mm}$ diameter) from colonies grown on PDA for 2 days at $23^{\circ} \mathrm{C}$ were distributed in petri dishes with a total of four pairings per dish. The dishes were kept at $23^{\circ} \mathrm{C}$ in the darkness. Mycelial compatibility was checked visually at 3 and 6 days of incubation. Each pairing was replicated at least twice. Control self-self pairings were also carried out at each round of testing. When the results were inconsistent, the pairing was replicated twice. S. sclerotiorum isolates were analyzed in all-pairwise combinations. Compatible isolates were distinguished by the absence of reaction line produced in the interaction zone between two isolates (Schafer and Kohn 2006).

Microsatellite genotyping. The isolates were genotyped as previously described (Lehner et al. 2015) using the microsatellite loci 7-2, 8-3, 9-2, 12-2, 13-2, 36-4, 42-4, 92-4, 106-4, and 114-4 (Sirjusingh and Kohn 2001). DNA of isolate LMK 211 was used as positive control since its microsatellite allele sizes had been previously determined. A sample without DNA was used as negative control. Both positive and negative controls were included in each run. A group of isolates was replicated three times with independent DNA extraction to confirm the reproducibility of the results. Data were processed with the GeneMarker Software V1.191 (Sounits Genetics). Each allele was determined according to the amplicon size of each isolate, taking into account the number of repeat units in each locus.

Analysis of DNA sequence of the oxaloacetate acetylhydrolase gene. PCR was performed in a final volume of $25 \mu \mathrm{l}$ with $1 \mu \mathrm{l}$ of DNA $(25 \mathrm{ng} / \mu \mathrm{l})$, $1 \mu \mathrm{l}$ of DMSO, $2.5 \mu \mathrm{l}$ of bovine serum albumin at $50 \mathrm{mg} / \mathrm{ml}, 1 \mu \mathrm{l}$ of each primer at $10 \mu \mathrm{M}, 6 \mu \mathrm{l}$ of water, and $12.5 \mu \mathrm{l}$ of Dream Taq PCR Master Mix (2x) that includes dATP, dCTP, dGTP, and dTTP (0.4 mM each) and $4 \mathrm{mM}$ of $\mathrm{MgCl}_{2}$ (Thermo Fisher Scientific). DNA fragments were amplified using the primer pair OAHaF (5'-CGAGTTGCCCTTCAAGTT-3') and OAHbR-deg (5'-CCACCAGCCGYAGTAT-3'), which flank a region of approximately $900 \mathrm{bp}$ of the OAH gene (Andrew et al. 2012). Each amplification reaction consisted of an initial denaturation at $95^{\circ} \mathrm{C}$ for $5 \mathrm{~min}$, followed by 40 cycles at $94^{\circ} \mathrm{C}$ for $30 \mathrm{~s}, 60^{\circ} \mathrm{C}$ for $30 \mathrm{~s}, 72^{\circ} \mathrm{C}$ for $30 \mathrm{~s}$, and a final extension at $72^{\circ} \mathrm{C}$ for $7 \mathrm{~min}$. Amplification was confirmed using $5 \mu \mathrm{l}$ of PCR product separated by electrophoresis on $1 \%$ agarose gel containing GelRed (Biotium, Hayward, CA). PCR products were purified using ExoSAP-IT cleanup reagent (USB, Cleveland, $\mathrm{OH}$ ) and sequenced by Macrogen Services (Kumchun-ku, Seoul, Korea) using OAHaF and OAHbR-deg primers. The nucleotide sequences were edited using DNA BASER sequence assembly software (HeracleBioSoft) and aligned using MEGA 5.0 (Tamura et al. 2011). In the alignment, we included the

Table 1. Microsatellite allele size in each locus and mycelial compatibility groups (MCG) of 20 Sclerotinia sclerotiorum isolates from four Brazilian states

\begin{tabular}{|c|c|c|c|c|c|c|c|c|c|c|c|c|c|}
\hline \multirow[b]{2}{*}{ Isolate code $\mathrm{e}^{\mathrm{a}}$} & \multirow[b]{2}{*}{ Municipality-State of collection ${ }^{b}$} & \multirow[b]{2}{*}{ Date of collection } & \multicolumn{10}{|c|}{ Allele size (bp) at each locus } & \multirow[b]{2}{*}{ MCG } \\
\hline & & & $7-2$ & $12-2$ & 13-2 & 114-4 & $9-2$ & $106-4$ & 8-3 & $92-4$ & $42-4$ & $36-4$ & \\
\hline Ss-2 & Oratórios-MG & Jun 2010 & 160 & 214 & 305 & 408 & 356 & 504 & 248 & 373 & 405 & 412 & 1 \\
\hline Ss- 8 & Canaã-MG & Jun 2010 & 160 & 216 & 305 & 408 & 356 & 504 & 248 & 373 & 405 & 412 & 1 \\
\hline Ss-19 & Viçosa & Jun 2010 & 162 & 218 & 285 & 408 & 356 & 504 & 248 & 373 & 407 & 412 & 1 \\
\hline Ss-23 & Porto Firme-MG & Jul 2010 & 160 & 212 & 305 & 408 & 356 & 504 & 248 & 373 & 407 & 412 & 1 \\
\hline Ss-44 & Paracatu-MG & Aug 2010 & 156 & 212 & 310 & 336 & 356 & 564 & 240 & 371 & 405 & 412 & 3 \\
\hline Ss-51 & Paracatu-MG & Aug 2010 & 156 & 212 & 310 & 336 & 356 & 568 & 240 & 371 & 405 & 412 & 3 \\
\hline Ss-56 & Unaí-MG & Aug 2010 & 160 & 216 & 310 & 336 & 356 & 572 & 240 & 371 & 405 & 412 & 3 \\
\hline Ss-70 & Unaí-MG & Aug 2010 & 172 & 222 & 305 & 412 & 356 & 568 & 254 & 375 & 405 & 410 & 2 \\
\hline Ss-79 & Unaí-MG & Aug 2010 & 170 & 216 & 305 & 408 & 356 & 568 & 248 & 375 & 405 & 412 & 2 \\
\hline Ss-136 & Itaí-SP & Nov 2011 & 160 & 214 & 310 & 336 & 356 & 520 & 242 & 371 & 405 & 414 & 4 \\
\hline Ss-138 & Capão Bonito-SP & Dec 2011 & 168 & 220 & 275 & 356 & 364 & 496 & 250 & 371 & 405 & 412 & 9 \\
\hline Ss-141 & Capão Bonito-SP & Dec 2011 & 160 & 216 & 305 & 408 & 356 & 504 & 250 & 373 & 405 & 412 & 1 \\
\hline Ss- 165 & Sta Maria Jetibá-ES & Jul 2012 & 172 & 220 & 305 & 408 & 356 & 568 & 250 & 375 & 405 & 412 & 2 \\
\hline Ss-166 & Sta Maria Jetibá-ES & Jul 2012 & 170 & 220 & 305 & 408 & 356 & 568 & 250 & 375 & 405 & 412 & 2 \\
\hline Ss-173 & Domingos Martins-ES & Jul 2012 & 160 & 216 & 285 & 408 & 356 & 504 & 250 & 373 & 405 & 412 & 7 \\
\hline Ss- 188 & Mauá da Serra-PR & Jul 2012 & 168 & 212 & 305 & 408 & 356 & 504 & 250 & 373 & 405 & 412 & 6 \\
\hline Ss-193 & Corbélia-PR & Jul 2012 & 168 & 220 & 290 & 356 & 356 & 572 & 250 & 373 & 405 & 412 & 8 \\
\hline Ss-196 & Reserva do Iguaçu-PR & Aug 2012 & 168 & 220 & 290 & 356 & 364 & 496 & 250 & 377 & 405 & 412 & 5 \\
\hline Ss-203 & TrêsBarras-PR & Jul 2012 & 160 & 220 & 305 & 408 & 356 & 504 & 250 & 371 & 405 & 412 & 10 \\
\hline Ss-217 & Itararé-SP & Aug 2012 & 158 & 214 & 310 & 336 & 356 & 528 & 242 & 371 & 405 & 412 & 4 \\
\hline
\end{tabular}

a The isolates Ss-2, Ss-8, Ss-19, Ss-23, Ss-44, Ss-51, Ss-56, Ss-70, and Ss-79 came from hyphal tips; the others from a single ascospore.

${ }^{\mathrm{b}} \mathrm{MG}=$ Minas Gerais state, $\mathrm{SP}=$ São Paulo state, $\mathrm{ES}=$ Espírito Santo state, $\mathrm{PR}=$ Paraná state. 
sequence of the $S$. sclerotiorum 1980 isolate, which had its genome recently sequenced (Amselem et al. 2011).

Aggressiveness assessment using the straw test. The cultivar Pérola and the line A195 were used. Pérola ("carioca" grain class, cream-striped) is widely used in Brazil and is susceptible to white mold (Vieira et al. 2010). The line A195 (beige colored grain with a distinctive yellow hilar ring) has partial white mold resistance (Singh et al. 2007). Experiments with each common bean genotype were carried out separately.

Plants were grown in 3-liter pots filled with the commercial substrate Tropstrato HT Hortaliças (Vida Verde, Mogi-Mirim, SP, Brazil) inside a greenhouse. This substrate has $\mathrm{pH} 5.8$ and is prepared with pine bark, processed peat, and vermiculite. Ten days after seedling emergence, $3 \mathrm{~g}$ of urea was distributed on the surface of every pot. A randomized design with four replicates was used. A pot with three plants (=experimental unit) was considered as a replicate.

Thirty days after planting, the main stem of the plants was cut $3 \mathrm{~cm}$ above the fourth node. A single 2-day-old mycelial disc from the first subculture of each isolate was punched with a 1,000- $\mu$ l Eppendorf pipette tip and capped over the cut stem of each plant. The length of the lesions was evaluated 7 days after inoculation. The experiments with each common bean genotype were performed twice.

Aggressiveness assessments using the detached leaflet test. The two common bean genotypes used for the straw test were also used here. Leaflets of the youngest fully expanded trifoliate leaves of 5-week-old plants were placed on filter paper moistened with $5 \mathrm{ml}$ of sterilized distilled water inside plastic boxes (11 width $\times$ 11 length $\times 3 \mathrm{~cm}$ height) (Gerbox). Two 2-day-old mycelial discs ( $5 \mathrm{~mm}$ diameter) from the first subculture of each isolate were placed between the main vein and the leaflet edges; one disc on each side of the main vein. Boxes containing inoculated leaves were kept at $23^{\circ} \mathrm{C}$ in the dark. The lesion diameter was assessed $48 \mathrm{~h}$ after inoculation using a digital caliper. Treatments were replicated four times in a completely randomized design. The experiments were performed twice.

Mycelial growth rate and sclerotia production at three temperatures. Mycelial plugs (5 mm diameter) from a 2-day-old culture were placed in the center of petri dishes $(6 \mathrm{~cm}$ diameter) containing $10 \mathrm{ml}$ of PDA with $100 \mathrm{mg} /$ liter of chloramphenicol. The dishes were kept at 18,23 , and $28^{\circ} \mathrm{C}$. Colony diameter was assessed at 24 and $29 \mathrm{~h}$ of incubation, and the average growth rate $(\mathrm{mm} / \mathrm{h})$ was estimated as: [(colony diameter measured at $29 \mathrm{~h}$ - colony diameter at $24 \mathrm{~h}) / 5$ ]. The number of sclerotia produced in each petri dish was counted after 15 days of incubation. A completely randomized design with three replicates was used. Each replicate was considered as one colony in a plate. The experiment was performed twice.

Mycelial pigmentation. Assessment of colony pigmentation was conducted in colonies formed in the petri dishes containing the mycelial plugs used in the previous experiment. Each colony was visually observed after 15 days of incubation and classified as nonpigmented, pigmented, and highly pigmented as previously described (Lehner et al. 2014).

Data analysis. Microsatellite analyses. Each isolate was assigned to a haplotype using GENODIVE (Meirmans and van Tienderen 2004). To assess the genetic relationships among the haplotypes, we used the Alerquin software (Excoffier and Lischer 2010) to construct a minimum spanning network.

Aggressiveness assessment by the straw and detached leaflet tests. Data were analyzed for homogeneity of variance using Bartlett's test. Data from two experiments were pooled for statistical analysis when variances were homogeneous; experiments were analyzed separately when variances were not homogeneous. Analysis of variance (ANOVA) was performed using the $\mathrm{R}$ program ( $\mathrm{R}$ Development Core Team, 2008). The overall mean and the standard deviation of the assessed variables were estimated for each cultivar. An isolate was considered less or more aggressive when the average of a given variable was either lower or greater, respectively, than the value of the overall mean plus or minus one standard deviation.

Mycelial growth rate and sclerotia production at three temperatures. The growing conditions for each of the three temperatures were considered as three independent experiments. Data were analyzed for homogeneity of variance using Bartlett's test. Additionally, the multivariate structure of the data were explored using a canonical discriminant analysis (CDA). Both analyses were performed in R.

Correlation analysis. The Mantel test was performed in GenAlex 6.41 with 10,000 permutations in order to estimate the correlation between the matrices of aggressiveness and genetic or phenotypic distances. The Bruvo's genetic distance (Bruvo et al. 2004) was calculated between all pairs of isolates using the Poppr package (Kamvar et al. 2014) for the R program. The Mahalanobis distance of aggressiveness or phenotypic data were also calculated using $\mathrm{R}$.

\section{Results}

Genetic diversity based on mycelial compatibility groups, microsatellite markers, and DNA sequences. Ten MCGs were found among the $20 \mathrm{~S}$. sclerotiorum isolates (Table 1). Each isolate was a distinct SSR haplotype (Table 1; Fig. 1). The number of alleles at each locus varied from one, at locus 36-4, to seven, at locus 7-2 and 106-4 (Table 1).

The partial DNA sequence of the AOH gene had 840 base pairs. The sequences of the Brazilian isolates shared 99.99 to $100 \%$ sequence similarity to $S$. sclerotiorum 1980 isolate (data not shown). Thirteen polymorphic sites and seven haplotypes were identified based on DNA sequence data (Fig. 2). The isolates Ss-188, Ss-196, and Ss-79 were single AOH haplotypes. The most frequent haplotype (H1) was detected in the isolates Ss-2, Ss-8, Ss-19, Ss-23, Ss-141, Ss-173, and Ss-203. Haplotype 2 was comprised of the isolates Ss-44, Ss-51, Ss56, Ss-138, and Ss-193; haplotype 3 of isolates Ss-70, Ss-165, Ss-166, and 1980; and haplotype 4 of isolates Ss-136 and Ss-217. The complete sequence of each haplotype is provided in Supplementary Figure S1.

Aggressiveness assessment using the straw and detached leaflet tests. The error variances for both experiments with cultivar Pérola for both straw and detached leaflet tests were similar, and the hypothesis of homoscedasticity could not be rejected. The effect of isolates on lesion length (straw test) was not significant $(\mathrm{F}=1.58$, $P=0.07$ ), but aggressiveness varied among isolates for the lesion diameter in the detached leaflet test $(\mathrm{F}=1.71, P=0.04)$.

With the line A195, variances between experiments were homogeneous in the detached leaflet test. Using the pooled data of the two experiments, aggressiveness varied among isolates $(\mathrm{F}=4.04, P<$ 0.001). Variances between experiments were heterogeneous in the straw test. There were significant differences between isolates in aggressiveness in experiments $1(\mathrm{~F}=3.27, P<0.001)$ and $2(\mathrm{~F}=2.06$, $P=0.018$ ).

In the straw test, the lesion length ranged from 5.7 (Ss-203) to $7.8 \mathrm{~cm}$ (Ss-136) for cv. Pérola (Fig. 3A). For line A195, lesion length varied from 1.9 (Ss-2) to $4.3 \mathrm{~cm}$ (Ss-79) in the first experiment, and from 6.3 (Ss-166) to $10.4 \mathrm{~cm}$ (Ss-217) in the second experiment (Fig. 3B). In the detached leaflet test, the lesion diameter varied from 32.4 (isolate Ss-165) to $41.3 \mathrm{~mm}$ (Ss-51) for cv. Pérola (Fig. 3C), and from 27.3 (Ss-138) to $40.2 \mathrm{~mm}$ (Ss-217) for A195 (Fig. 3D). There was no difference regarding isolate aggressiveness for cv. Pérola (Fig. 3A and B), whereas for A195 the isolate Ss-217 was more aggressive than the other isolates (Fig. 3B and D). Isolate Ss-136 had the second largest average values of lesion diameter and length (Experiment 2) when inoculated on plants of A195 (Fig. 3B and D). However, the value of lesion diameter did not differ from the overall mean.

Mycelial growth rate and sclerotia production at three temperatures. Variances between experiments were homogeneous. Incubation at $18^{\circ} \mathrm{C}(\mathrm{F}=5.20, P<0.001), 23^{\circ} \mathrm{C}(\mathrm{F}=9.23, P<0.001)$, or $28^{\circ} \mathrm{C}(\mathrm{F}=4.71, P<0.001)$ affected the mycelial growth rate of the isolates. The average mycelial growth rate at $18^{\circ} \mathrm{C}$ ranged from $1.50 \pm$ 0.43 (isolate Ss-138) to $2.20 \pm 0.31 \mathrm{~mm} / \mathrm{h}$ (Ss-203) (Supplementary Table S1). At $23^{\circ} \mathrm{C}$, growth rates varied from $1.77 \pm 0.40 \mathrm{~mm} / \mathrm{h}$ (Ss79 ) to $2.65 \pm 0.15$ (Ss-203). The mycelial growth rate of isolates at $28^{\circ} \mathrm{C}$ was on average two times lower than that at $23^{\circ} \mathrm{C}$. At $28^{\circ} \mathrm{C}$, the mycelial growth rate ranged from $0.64 \pm 0.12$ (Ss-173) to $1.48 \pm$ $0.08 \mathrm{~mm} / \mathrm{h}$ (Ss-79).

Isolates affected the number of sclerotia produced at either $18^{\circ} \mathrm{C}(\mathrm{F}=$ $1.75, P=0.04)$ or at $23^{\circ} \mathrm{C}(\mathrm{F}=2.91, P<0.001)$. The number of sclerotia 
per plate at $18^{\circ} \mathrm{C}$ varied from $19 \pm 4$ (isolate Ss-2) to $33 \pm 8$ (Ss-165). The number of sclerotia per plate at $23^{\circ} \mathrm{C}$ varied from $11 \pm 3$ (Ss188 ) to $30 \pm 16$ (Ss-23). Isolates of $S$. sclerotiorum did not produce sclerotia at $28^{\circ} \mathrm{C}$.

The first two canonical variables captured $73.4 \%$ of the total variation of the morphological traits. Despite the high variability in mycelial growth rate and sclerotia production, CDA did not indicate distinct groups of isolates (Fig. 4).

Colony color. Isolates exhibited differences in mycelial pigmentation. The colonies of isolates classified as nonpigmented were white in color, the pigmented ones were brown, and the highly pigmented were black colonies. Isolates Ss-138, Ss-193, and Ss-196 were nonpigmented. Isolates Ss-44, Ss-51, Ss-56, Ss-136, and Ss217 were highly pigmented, whereas the other isolates were classified as pigmented (Fig. 1).
Correlations. Correlations between aggressiveness and either genetic distance (based on SSR data) $(\mathrm{r}=-0.03, P=0.40)$ or phenotypic distance (based on mycelial growth rate and sclerotia production) ( $\mathrm{r}=0.17, P=0.10)$ were low and not significant.

\section{Discussion}

S. sclerotiorum is the most harmful soilborne pathogen of common bean in Brazil and other countries such as the United States, Canada, and Argentina (Schwartz and Singh 2013). Thus, understanding the aggressiveness of the pathogen is valuable to improve the effectiveness of control practices, particularly the strategic use of cultivar resistance. We used two inoculation methods and two common bean genotypes to assess the aggressiveness of $20 \mathrm{~S}$. sclerotiorum isolates from four Brazilian states. We did not estimate the incubation period due to the inherent difficulties in accurately assessing initial

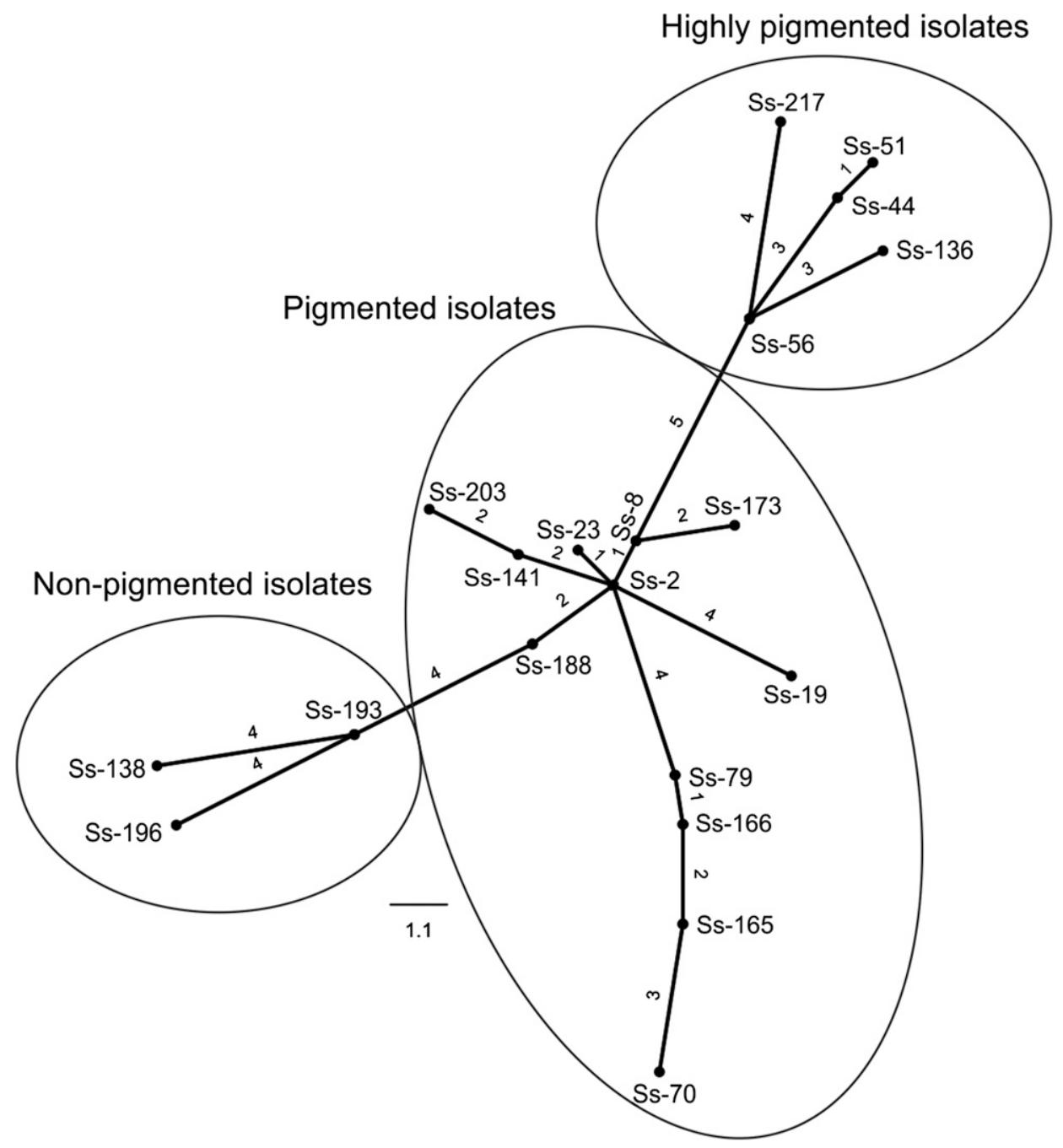

Fig. 1. Minimum spanning network based on 10 SSR loci and mycelial pigmentation of Sclerotinia sclerotiorum isolates sampled from common bean fields in Brazil. Each node represents a haplotype. The number of loci by which one haplotype differs from another is represented between the nodes.

H1 (Ss-2; 8; 19; 23; 141; 173 and 203)
H2 (Ss-44; 51; 56; 138 and 193)
H3 (Ss-70; 165 and 166)
H4 (Ss-136 and 217)
H5 (Ss-79)
H6 (Ss-188)
H7 (Ss-196)
Sclerotinia sclerotiorum 1980 isolate

$\begin{array}{lllllllllllllll}295 & 339 & 383 & 392 & 443 & 467 & 526 & 561 & 637 & 736 & 803 & 969 & 972 & 1116 & 1135\end{array}$

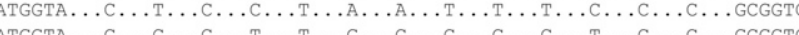

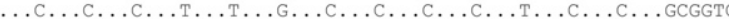

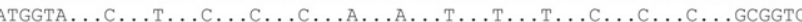

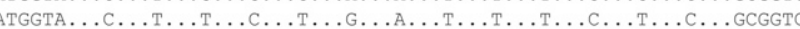

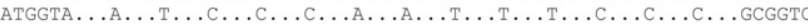

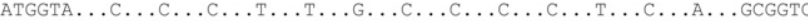

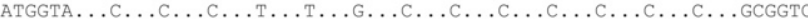

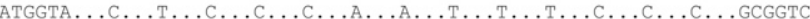

Fig. 2. Polymorphic sites found in the partial sequences of the oxaloacetate acetylhydrolase gene of Sclerotinia sclerotiorum isolates from common bean. Dotted lines indicate identical sequences among the haplotypes. The numbers above the nucleotide refer to its position in the sequence of the complete gene mapped in the $S$. sclerotiorum genome. 

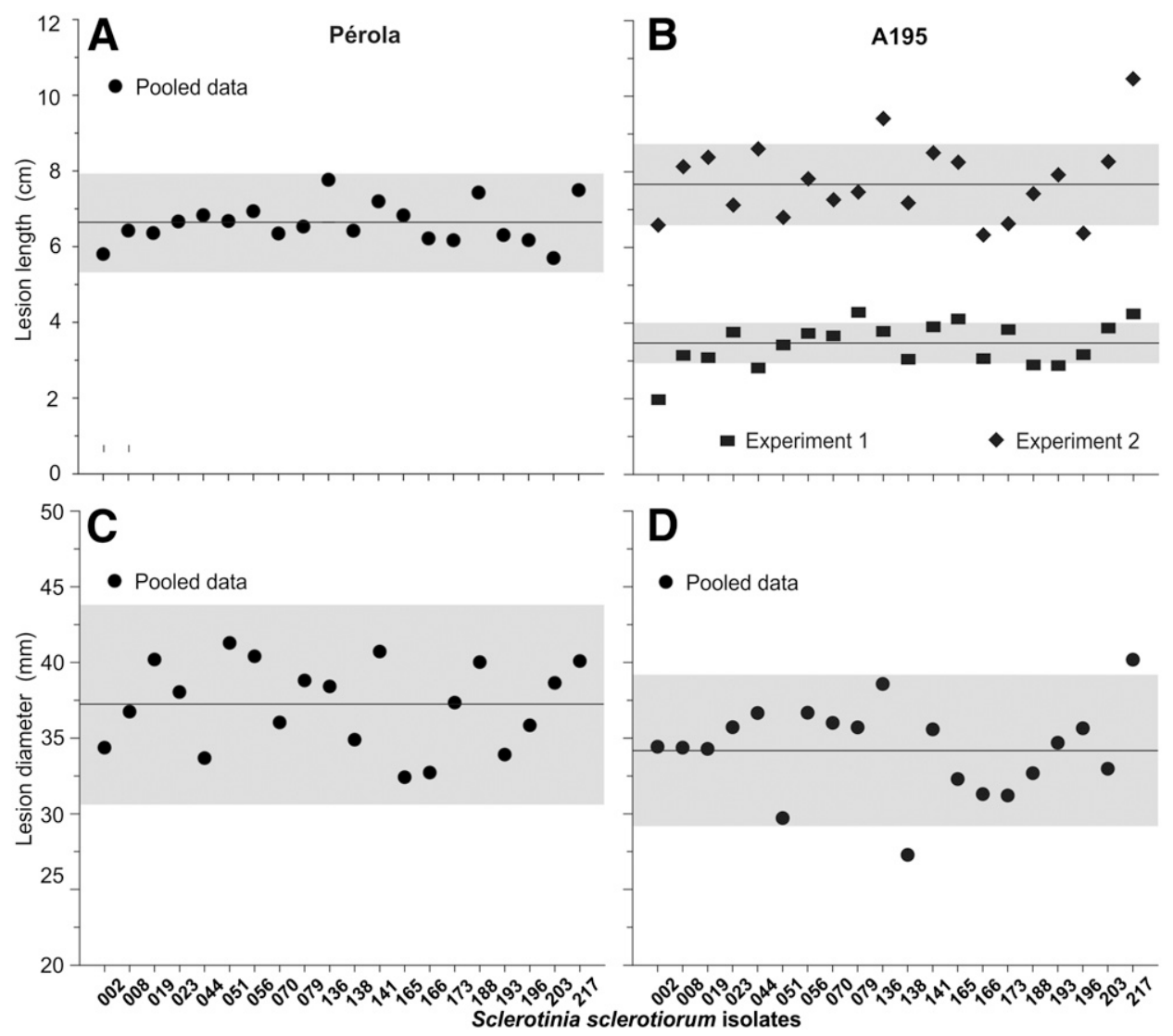

Fig. 3. Stem lesion length measured in the straw test and lesion diameter on leaflets of common bean genotypes, Pérola (A and C) and A195 (B and D). The lines indicate the overall mean of each variable. Gray bands correspond to the one standard deviation around the mean.

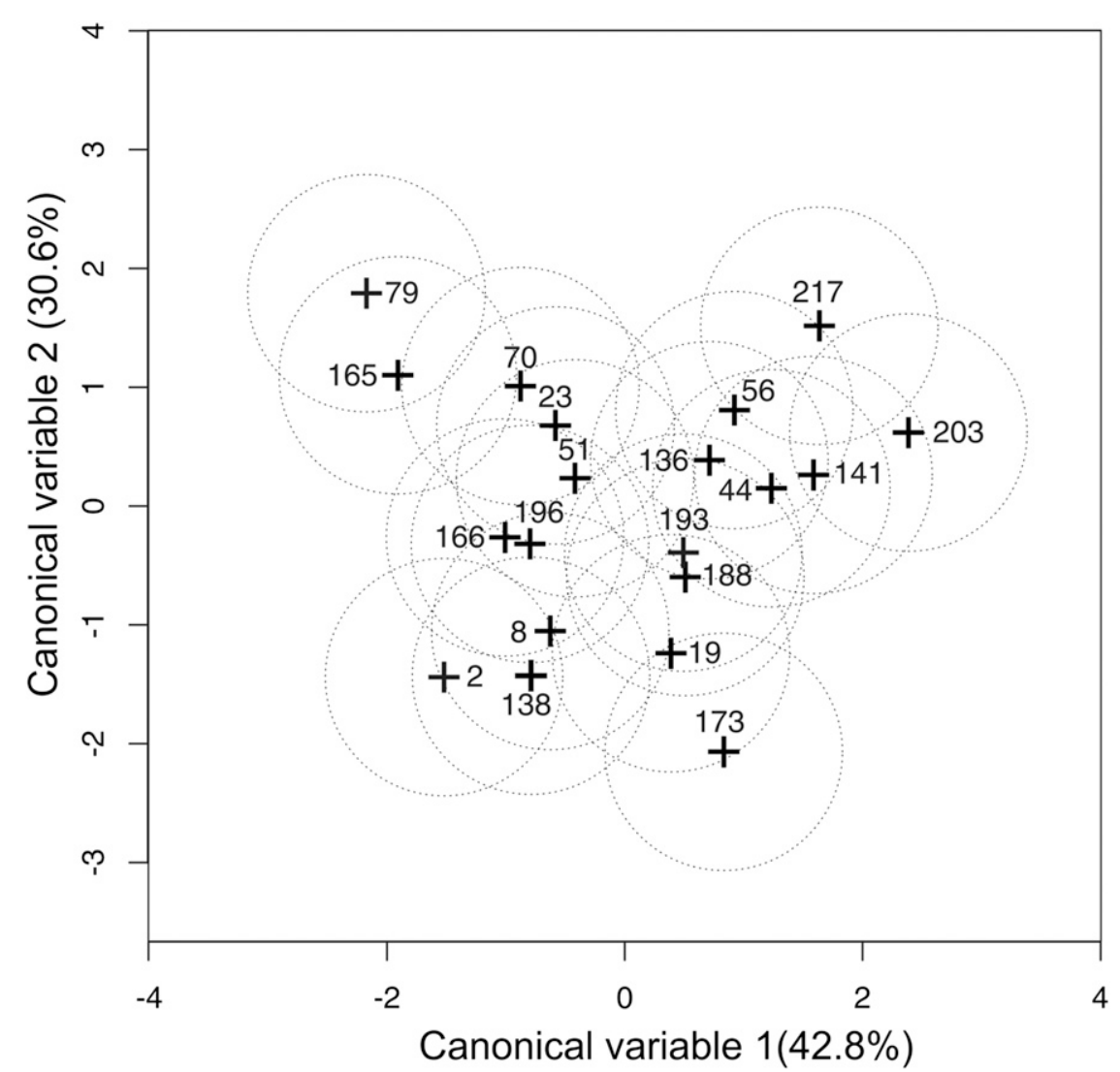

Fig. 4. Canonical discriminant analysis of the phenotypic variation observed among the 20 Sclerotinia sclerotiorum isolates. Dotted circles indicate the confidence region at $95 \%$ probability. 
symptom development. The incubation period of white mold in common bean is generally short and, given the necrotrophic nature of the fungus, plant cell damage occurs within $6 \mathrm{~h}$ of inoculation (Lumsden and Dow 1973). Latent period was not assessed, because it does not convey useful information for the purpose of estimating aggressiveness. The hyphae of S. sclerotiorum are formed on damaged cells (Lumsden and Dow 1973), so the latent period is of limited utility to determine genotype resistance, since extensive necrosis has already occurred.

The detached leaflet and the straw test are effective methods to assess the aggressiveness of $S$. sclerotiorum isolates (Kull et al. 2003). The results of the present study corroborate these findings, since we observed that the aggressiveness of isolates did not change with the inoculation method. On the other hand, aggressiveness was affected by common bean cultivar. When the cv. Pérola was used, aggressiveness of the isolates was similar, regardless of the inoculation method. Using A195, however, the most aggressive isolate was Ss-217. Thus, A195 seems to be more suited to use in aggressiveness tests than cv. Pérola. One possible explanation for the lack of variation in aggressiveness when using cv. Pérola is that this cultivar is more susceptible to white mold than is A195. Pérola probably has fewer resistance genes, given that A195 is considered partially resistant to white mold (Singh et al. 2007).

Aggressiveness of $S$. sclerotiorum has been a subject of many studies in different crops. Uniformity (Atallah et al. 2004; Sexton and Howlett 2004) as well as aggressiveness variation among isolates (Attanayake et al. 2013; Ekins et al. 2007; Kull et al. 2004; Otto-Hanson et al. 2011) have been reported. Thus, direct comparisons of experimental results must be done carefully, since isolate variability, inoculation method, host species, and environmental conditions of the experiments may affect the results. Cultivar resistance also affects the results and this was clearly demonstrated in the present study, where the higher aggressiveness of the isolate Ss-217 was demonstrated to be dependent on common bean genotype.

One goal of this study was to evaluate the possible correlation between aggressiveness and genetic variability of the isolates. We found similar aggressiveness levels among 20 SSR haplotypes and no correlation between genetic distance and aggressiveness. High genotypic diversity based on SSR markers was found among 35 S. sclerotiorum isolates from potato in the United States, but there was no variation in aggressiveness (Atallah et al. 2004). Similar results were reported for $43 \mathrm{~S}$. sclerotiorum isolates from canola in Australia (Sexton and Howlett 2004). Contrary to these reports, differences in aggressiveness among SSR haplotypes of S. sclerotiorum collected in canola fields from the United States and China were detected (Attanayake et al. 2013). The lack of relation between the SSR markers and aggressiveness found in the present study is not surprising. These markers are selectively neutral, although numerous studies have documented some functional importance of SSR loci (for a review, see Li et al. 2002). In addition, aggressiveness is a multigenic trait and any association between this characteristic and a SSR locus is highly unlikely.

Isolates Ss-136 and Ss-217 were slightly more aggressive when tested on A195. They shared an identical DNA sequence of the $\mathrm{OAH}$ gene. It is known that oxalic acid is essential for the pathogenicity of S. sclerotiorum (Amselem et al. 2011), so it is possible that mutations in the $\mathrm{OAH}$ gene may interfere in the aggressiveness of isolates. Our results suggest that different SSR haplotypes of S. sclerotiorum do not necessarily have different aggressiveness levels in common bean. The pathogenic loci of S. sclerotiorum probably evolved independently of SSR loci, leading to a lack of association between aggressiveness and SSR haplotypes, as postulated for Phytophthora infestans (Goodwin et al. 1995). Therefore, further research should involve evaluations of the polymorphism in pathogenic loci and their effects on the aggressiveness of S. sclerotiorum isolates.

In some pathosystems, MCG and aggressiveness were demonstrated to be associated (Douhan and Johnson 2001; Remesal et al. 2012). In S. sclerotiorum, there are studies reporting lack of variation (Atallah et al. 2004; Sexton and Howlett 2004) as well as differences in aggressiveness among MCGs (Attanayake et al. 2013; Irani et al.
2011; Kull et al. 2004; Otto-Hanson et al. 2011). In our study, isolates Ss-136 and Ss-217 belong to the same MCG and were slightly more aggressive in A195. The remaining isolates, although divided into nine other MCGs, had similar aggressiveness levels. Therefore, we have no evidence of association between MCGs and aggressiveness.

High variability in mycelial growth rate at 18,23 , and $28^{\circ} \mathrm{C}$ and sclerotia production at 18 and $23^{\circ} \mathrm{C}$ were found. Nevertheless, these characteristics were uninformative, because they did not allow separation of the isolates into distinct groups. In addition, there was no correlation between phenotypic and aggressiveness distance. When analyzing the Pearson's correlation coefficient between each pair of variables, we found significant correlation only between lesion length on A195 and mycelial growth rate at $28^{\circ} \mathrm{C}(\mathrm{r}=0.51, P=$ $0.021)$ and number of sclerotia at $23^{\circ} \mathrm{C}(\mathrm{r}=0.56, P=0.009)$ and between mycelial growth rate at $28^{\circ} \mathrm{C}$ and lesion diameter on A195 $(\mathrm{r}=$ $0.53, P=0.015$ ) (data not shown). Due to the low magnitude and the lack of association, these correlations seem to have occurred randomly. These results are consistent with those of another study (Irani et al. 2011) and suggest that sclerotial production and mycelial growth rate have no influence on the aggressiveness of S. sclerotiorum isolates.

Isolates Ss-44, Ss-51, Ss-56, Ss-136, and Ss-217 have black mycelia and probably produce high amounts of melanin. An association of melanin and pathogenicity or aggressiveness has been reported in Colletotrichum lagenarium, Magnaporthe grisea (Howard and Ferrari 1989), and Bipolaris sorokiniana (Chand et al. 2014). Melanin may be involved in pressure buildup in the appressorium, providing forces for mechanical penetration in the host cell (Howard and Ferrari 1989). It may also provide rigidity in the cell wall, decreasing the pore size, meaning that a lower quantity of extracellular enzymes is released (Chand et al. 2014). In the present study all isolates were pathogenic to common bean, regardless of the site of inoculation (leaflets or stems) or melanin intensity. This result may be explained by the fact that $S$. sclerotiorum does not depend on pressure mediated by melanin in appressoria for penetration in the host cell. In addition to mechanical force via appressoria, the pathogen can penetrate the cuticle of the host plant using enzymes (Hegedus and Rimmer 2005). Contrary to what is reported in the current study, melanin content was negatively correlated with extracellular enzymes and consequently aggressiveness in B. sorokiniana (Chand et al. 2014). Although isolates Ss-136 and Ss-217 had been slightly more aggressive when tested in A195, other highly pigmented isolates showed aggressiveness levels similar to those of pigmented and nonpigmented isolates. Therefore, we did not find a direct relationship between mycelial pigmentation and pathogenicity or aggressiveness. Similar results were reported for eight $S$. sclerotiorum isolates (three darkly pigmented) collected from rape in Australia (Garg et al. 2010).

This study has found similar aggressiveness levels among the 20 S. sclerotiorum isolates from common bean collected in four Brazilian states. Although the number of isolates analyzed has been relatively small, the variability of S. sclerotiorum causing white mold on common bean in Brazil is low (Lehner et al. 2015). Therefore, the results can be used to make inferences about the population. Nevertheless, the existence of highly aggressive isolates cannot be ruled out, given our sampling limitation.

\section{Acknowledgments}

M.S. Lehner, T. J. Paula Júnior, R. F. Vieira, J. E. S. Carneiro, and E. S. G. Mizubuti were supported by Conselho Nacional de Desenvolvimento Científico e Tecnológico - CNPq. R. C. Lima was supported by Coordenação de Aperfeiçoamento de Pessoal de Nível Superior - CAPES. This research was supported by FAPEMIG and CNPq. The authors thank Dr. Linda Kohn for sending DNA of S. sclerotiorum isolate LMK211.

\section{Literature Cited}

Abd-Elmagid, A., Garrido, P. A., Hunger, R., Lyles, J. L., Mansfield, M. A., Gugino, B. K., Smith, D. L., Melouk, H. A., and Garzon, C. D. 2013. Discriminatory simplex and multiplex PCR for four species of the genus Sclerotinia. J. Microbiol. Methods 92:293-300.

Amselem, J., Cuomo, C. A., van Kan, J. A. L., Viaud, M., Benito, E. P., Couloux, A., et al. 2011. Genomic analysis of the necrotrophic fungal pathogens Sclerotinia sclerotiorum and Botrytis cinerea. PLoS Genet. 7:e1002230. 
Andrew, M., Barua, R., Short, S. M., and Kohn, L. M. 2012. Evidence for a common toolbox based on necrotrophy in a fungal lineage spanning necrotrophs, biotrophs, endophytes, host generalists and specialists. PLoS One 7:e29943.

Atallah, Z. K., Larget, B., Chen, X., and Johnson, D. A. 2004. High genetic diversity, phenotypic uniformity, and evidence of outcrossing in Sclerotinia sclerotiorum in the Columbia basin of Washington State. Phytopathology 94: 737-742.

Attanayake, R. N., Carter, P. A., Jiang, D., del Río-Mendoza, L., and Chen, W. 2013. Sclerotinia sclerotiorum populations infecting canola from China and the United States are genetically and phenotypically distinct. Phytopathology 103:750-761.

Boland, G. J., and Hall, R. 1994. Index of plant hosts of Sclerotinia sclerotiorum. Can. J. Plant Pathol. 16:93-108.

Bruvo, R., Michiel, N. K., D’Souza, T. G., and Schulenburg, H. 2004. A simple method for the calculation of microsatellite genotype distances irrespective of ploidy level. Mol. Ecol. 13:2101-2106.

Carneiro, F. F., Santos, J. B., and Leite, M. E. 2010. Marker-assisted backcrossing using microsatellites and validation of SCAR Phs marker for resistance to white mold in common bean. Electron. J. Biotechnol. 13:1-7.

Carvalho, R. S. B., Lima, I. A., Alves, F. C., and Santos, J. B. 2013. Selection of carioca common bean progenies resistant to white mold. Crop Breed. Appl. Biotechnol. 13:172-177.

Chand, R., Kumar, M., Kushwaha, C., Shah, K., and Joshi, A. K. 2014. Role of melanin in release of extracellular enzymes and selection of aggressive isolates of Bipolaris sorokiniana in barley. Curr. Microbiol. 69:202-211.

Douhan, L. I., and Johnson, D. A. 2001. Vegetative compatibility and patho genicity of Verticillium dahliae from spearmint and peppermint. Plant Dis. 85:297-302.

Ekins, M. G., Aitken, E. A. B., and Goulter, K. C. 2007. Aggressiveness among isolates of Sclerotiniasclerotiorum from sunflower. Australas. Plant Pathol. 36:580-586.

Excoffier, L., and Lischer, H. E. 2010. Arlequin suite ver 3.5: a new series of programs to perform population genetics analyses under Linux and Windows. Mol. Ecol. Resour. 10:564-567.

Garg, H., Kohn, L. M., Andrew, M., Li, H., Sivasithamparam, K., and Barbetti, M. J. 2010. Pathogenicity of morphologically different isolates of Sclerotinia sclerotiorum with Brassica napus and B. juncea genotypes. Eur. J. Plant Pathol. 126:305-315.

Goodwin, S. B., Sujkowski, L. S., and Fry, W. E. 1995. Rapid evolution of pathogenicity within clonal lineages of the potato late blight disease fungus. Phytopathology 85:669-676.

Hegedus, D. D., and Rimmer, S. R. 2005. Sclerotinia sclerotiorum: When "to be or not to be" a pathogen? FEMS Microbiol. Lett. 251:177-184.

Howard, R. J., and Ferrari, M. A. 1989. Role in melanin appressorium function. Exp. Mycol. 13:403-418.

IBGE. 2015. Levantamento sistemático da producão agrícola. Online: http: //www.ibge.gov.br/home/estatistica/indicadores/agropecuaria/lspa/default. shtm, accessed 7 April 2015.

Irani, H., Heydari, A., Javan-Nikkhah, M., and İbrahimov, A. Ş. 2011. Pathogenicity variation and mycelial compatibility groups in Sclerotinia sclerotiorum. J. Plant Prot. Res. 51:329-336.

Kamvar, Z. N., Tabima, J. F., and Grunwald, N. J. 2014. Poppr: an R package for genetic analysis of populations with clonal, partially clonal, and/or sexual reproduction. PeerJ 2:e281.

Kull, L. S., Pederson, W. L., Palmquist, D., and Hartman, G. L. 2004. Mycelial compatibility grouping and aggressiveness of Sclerotinia sclerotiorum. Plant Dis. 88:325-332.
Kull, L. S., Vuong, T. D., Powers, K. S., Eskridge, K. M., Steadman, J. R., and Hartman, G. L. 2003. Evaluation of resistance screening methods for Sclerotinia stem rot of soybean and dry bean. Plant Dis. 87:1471-1476.

Lehner, M. S., Paula Júnior, T. J., Hora Júnior, B. T., Teixeira, H., Vieira, R. F., Carneiro, J. E. S., and Mizubuti, E. S. G. 2015. Low genetic variability in Sclerotinia sclerotiorum populations from common bean fields in Minas Gerais State, Brazil, at regional, local and micro scales. Plant Pathol. 64:921-931.

Lehner, M. S., Paula Júnior, T. J., Silva, R. A., Vieira, R. F., Carneiro, J. E. S., and Mizubuti, E. S. G. 2014. Sclerotia morphology traits and mycelial growth rate are not informative variables for population studies of Sclerotinia sclerotiorum. Trop. Plant Pathol. 39:471-477.

Li, Y.-C., Korol, A., Fahima, T., Beiles, A., and Nevo, E. 2002. Microsatellites: genomic distribution, putative functions and mutational mechanisms: a review. Mol. Ecol. 11:2453-2465.

Lumsden, R., and Dow, R. L. 1973. Histopathology of Sclerotinia sclerotiorum infection of bean. Phytopathology 63:708-715.

Meirmans, P. G., and van Tienderen, P. H. 2004. GENOTYPE and GENODIVE: Two programs for the analysis of genetic diversity of asexual organisms. Mol. Ecol. Notes 4:792-794.

Miklas, P. N., Porter, L. D., Kelly, J. D., and Myers, J. R. 2013. Characterization of white mold disease avoidance in common bean. Eur. J. Plant Pathol. 135:525-543.

Otto-Hanson, L., Steadman, J. R., Higgins, R., and Eskridge, K. M. 2011. Variation in Sclerotinia sclerotiorum bean isolates from multisite resistance screening locations. Plant Dis. 95:1370-1377.

Pascual, A., Campa, A., Pérez-Vega, E., Giraldez, R., Miklas, P. N., and Ferreira, J. J. 2010. Screening common bean for resistance to four Sclerotinia sclerotiorum isolates collected in Northern Spain. Plant Dis. 94:885-890.

Petzoldt, R., and Dickson, M. H. 1996. Straw test for resistance to white mold in beans. Annu. Rep. Bean Improv. Coop. 39:142-143.

Remesal, E., Jordan-Ramírez, R., Jimenez-Díaz, R. M., and Navas-Cortes, J. A. 2012. Mycelial compatibility groups and pathogenic diversity in Sclerotium rolfsii populations from sugar beet crops in Mediterranean-type climate regions. Plant Pathol. 61:739-753.

Schafer, M. R., and Kohn, L. M. 2006. An optimized method for mycelia compatibility testing in Sclerotinia sclerotiorum. Mycologia 98:593-597.

Schwartz, H. F., and Singh, S. P. 2013. Breeding common bean for resistance to white mold: A review. Crop Sci. 53:1832-1844.

Sexton, A. C., and Howlett, B. J. 2004. Microsatellite markers reveal genetic differentiation among populations of Sclerotinia sclerotiorum from Australian canola fields. Curr. Genet. 46:357-365.

Singh, S. P., Terán, H., Lema, M., Schwartz, H. F., and Miklas, P. N. 2007. Registration of white mold resistant dry bean germplasm line A195. J. Plant Reg. 1:62-63.

Sirjusingh, C., and Kohn, L. M. 2001. Characterization of microsatellites in the fungal plant pathogen, Sclerotinia sclerotiorum. Mol. Ecol. Notes 1:267-269.

Steadman, J. R., Powers, K., and Higgins, B. 1997. Screening common bean for white mold resistance using detached leaves. Annu. Rep. Bean Improv. Coop. 40:140-141

Tamura, K., Peterson, D., Peterson, N., Stecher, G., Nei, M., and Kumar, S. 2011 MEGA5: Molecular evolutionary genetics analysis using maximum likelihood, evolutionary distance, and maximum parsimony methods. Mol. Biol. Evol. 28: 2731-2739.

Vieira, R. F., Paula Júnior, T. J., Teixeira, H., and Carneiro, J. E. S. 2010. White mold management in common bean by increasing within-row distance between plants. Plant Dis. 94:361-367.

Vuong, T. D., Hoffman, D. D., Diers, B. W., Miller, J. F., Steadman, J. R., and Hartman, G. L. 2004. Evaluation of soybean, dry bean, and sunflower for resistance to Sclerotinia sclerotiorum. Crop Sci. 44:777-783. 